\title{
Kahramanmaraş Sütçü İmam Üniversitesi Sağlık Uyg. ve Araşt. Hastanesi Çalışanlarında Hepatit B ve C Enfeksiyonu Seropozitifliğinin Araştırılması
}

Investigation of Seropositivity of Hepatitis B and C Infection in Kahramanmaraş Sütçü İmam University Health Practice and Research Hospital Workers

Gökhan ARICAN ${ }^{1}$, Hacer UĞURLU², Burak Küçüik ${ }^{2}$, Murat ARAL $^{2}$, Gürkan MURATDAĞI ${ }^{3}$

${ }^{1}$ Kahramanmaraş Sütçü İmam Üniversitesi Tip Fakültesi Hastanesi Eczanesi, Kahramanmaraş

${ }^{2}$ Kahramanmaraş Sütçü Imam Üniversitesi Tip Fakültesi Hastanesi, Mikrobiyoloji A.D, Kahramanmaraş

${ }^{3}$ Sakarya Üniversitesi Tip Fakültesi, Aile Hekimliği A.D, Sakarya

Yazı̧ma Adresi / Correspondence:
Murat Aral
KSÜ Tip Fakültesi Mikrobiyoloji Labaratuvarı Anabilimdalı Başkanlı̆̆ı, Kahramanmaraş
T: +90 5336496123 E-mail : aralmurat@hotmail.com
Geliş Tarihi / Received : 29.04.2019 Kabul Tarihi / Accepted : 01.10.2019
Orcid :
Murat Aral https://orcid.org/: 0000-0002-3576-4380
Gökhan Arıcan https://orcid.org/0000-0002-2002-1904
Burak Küçük https://orcid.org/0000-0001-5596-3347
Hacer Uğurlu https://orcid.org/0000-0001-6126-5502
Gürkan Muratdağı https://orcid.org/0000-0002-9629-3973
( Sakarya Tip Dergisi / Sakarya Med J 2019, 9(4):592-596) Dol: 10.31832/smj.559018

$\ddot{\mathrm{O} z}$

Amaç Sağllk kurumlarında calıșan personellere kan ve vücut sıvlarılya temas sonrası ya da delici-kesici alet batması sonucu Hepatit B (HBV) ve Hepatit C (HCV) bulaşabilmektedir. Bu çalışmada 2017-2018 yılları arasında Kahramanmaraş Sütçü İmam Úniversitesi (KSƯ) Sağllk Uygulama ve Araștırma Hastanesinde görevli 400 Sağlık çalışanında HBV, HCV seropozitiflik oranının araştırılması amaçlanmıştır.

Gereç ve 2017-2018 yılları arasında hastanemizde çalıșan 400 personele ait kayıtlar retrospektif olarak incelenmiștir. Bu incelemede, tarama amacıyla alınan kan örneklerinde Yöntemler kemilüminesans esasına dayanan “Enzyme-Linked Immunosorbent Assay” (ELISA) yöntemiyle çalıșlan HBsAg ve anti-HCV parametreleri saptanmıștır.

Bulgular Çalışmaya dahil edilen 400 hastane personelinin 160’ (\%40) erkek, 240’1 (\%60) kadın olarak saptanmıștır. Çalıșanlardan 339’u (\%84.7) sağlık ekibi ( hemșire, laborant, sağlık teknisyeni, eczacı), 61’i (\%15.3) diğer çalıșan grubundan (bilgisayar ișletmeni, șef, șoför, teknisyen) olușmaktadır. 400 hastane personelinin 10’unda (\%2.5) HBsAg, l'inde (\%0.25) anti-HCV pozitif olarak bulunmuştur.

Sonuç KSÜ Sağlık Uygulama ve Araștırma Hastanesindeki sağlık çalıșanlarında HBV, HCV seropozitiflik düzeyleri Türkiyede yapılan diğer çalıșmalarla uyumlu bulunmuştur. Yüksek risk altında bulunan sağlık personellerinin bu virüsler açısından taranması ve HBV’ye karşı bağıșık olmayanlarının aşılanması önerilmektedir.

Anahtar HBV; HCV; Sağlık çalışanları; Seropozitiflik

Kelimeler

Abstract

Objective Hepatitis B (HBV) and Hepatitis C (HCV) can be transmitted to the personnel after contact with blood and body fluids or by penetration of penetrating-cutting tools, who are working in health institutions. In this study, we aimed to investigate the HBV and HCV seropositivity in 400 health care workers in Kahramanmaraş Sütçü Imam University (KSU) Health Application and Research Hospital between 2017-2018.

The records of 400 personnel working in our hospital between 2017-2018 were analyzed retrospectively. In this analyze, blood samples received in order to scan HBsAg and anti-HCV parameters detected by the method "Enzyme-Linked Immunosorbent Assay" (ELISA) based on the basis of chemiluminescence immunoassay were determined.

Results $160(\% 40)$ persons were male, whereas $240(\% 60)$ persons of the 400 hospital personnels were woman. $339(\% 84.7)$ of the employees were from the health care team (nurses, laborants, health technicians, pharmacists) and 61 (\%15.3) were from the other employees ( computer operators, chefs, drivers, technician). HBsAg was positive in 10 (\%2.5) and anti-HCV was positive in 1 (\%0.2) of 400 hospital staff.

Conclusion Among health workers of KSU Health Application and Research Hospital, the HBV HCV seropositive levels has been found compatible with other studies made in Turkey. It is recommended to screen these viruses in high-risk healthcare personnel and immunized them against $\mathrm{HBV}$ who are not immunized.

Keywords HBV; HCV; Health workers; Seropositiveness 


\section{GIIRIŞ}

İnsan sağlığı ile çalışma ortamı arasında oldukça yakın ve doğrudan bir ilişki bulunmaktadır. Özellikle sağlık sektörü çalışanları, hastalardan ve bulundukları fiziki çevreden (laboratuar, ameliyathane, poliklinikler vb.) bulaşabilecek pek çok enfeksiyöz etkenler karşısında yüksek risk altındadır. Hastanelerin, çalışan personel için barındırdığı riskler arasında hepatit B virüsü (HBV), hepatit $C$ virüsü’nün (HCV) neden olduğu enfeksiyonlar ilk siralarda yer almaktadır. ${ }^{1,2}$ Hepatit B, dünyada ve ülkemizde en yaygın görülen enfeksiyonlardan biridir. Dünyada yaklaşık 450500 milyon, ülkemizde 3-4 milyon kişinin HBV taşıyıcısı olduğu ve Hepatit B’nin dünyada her yıl yaklaşık 1-2 milyon kişinin ölümüne yol açtığı bildirilmiştir. ${ }^{3}$ Dünyada HBV taşıyıcılığının ortalama \%6,5 olduğu bildirilmiştir. ${ }^{4}$ Yurdumuz HBV taşıyıcılığ 1 açısından orta endemisite bölgeleri (\%3-7) arasında yer almaktadır. 1992 yılında, Dünya Sağlık Örgütü (DSÖ) HBV enfeksiyonunu meslek hastalığı olarak kabul etmiş; 1996 yılında, T. C. Sağlık Bakanlığı sağlık çalışanlarının HBV yönünden taranıp uygun kişilerin aşılanmasını başlatmıştır. Aşılama programlarının yaygınlaşması, toplumsal bilincin ve farkındalığın artmasına rağmen, HBV enfeksiyonları halen önemini korumaktadır. Ülkemizde HBV taşıyıcılığı \%2-10 arasındadır. Çalışmalarda sağlık personelinde ise bu oranın 1,5-2 kat daha fazla olduğu bildirilmektedir. ${ }^{5}$

HCV, HBV’ye göre daha sık kronik hepatite ve siroza neden olabilen bir virüstür. ${ }^{21}$ Hepatit C prevalansının HBV'den daha düşük $(\% 0,2-2)$ olduğu bilinmektedir. ${ }^{7}$ Dünyada yaklaşık 300 milyon, ülkemizde ise 600 bin kişinin Hepatit $\mathrm{C}$ virüsü (HCV) ile enfekte olduğu tahmin edilmektedir. ${ }^{8}$ HCV prevalansı dünyada \%0,5-2 arasında değişmektedir. Türkiye'de ise raporlara göre değişmekle beraber sağlık personellerinde ise \%1,6 olarak bildirilmektedir. ${ }^{4}$ HBV'de parenteral, HCV'de gerek parenteral gerekse nozokomiyal geçişin söz konusu olması ve kronik karaciğer hastalıklarına sebebiyet vermeleri sağlık çalışanları için ciddi bir problem teşkil etmektedir. ${ }^{23}$
Bu çalışmada hastanemizin tüm ünitelerinde görev yapan çalışanlarında HBsAg ve anti-HCV serolojisini saptayarak aşılanmalarının sağlanması, infekte personelin belirlenip takip ve tedavi altına alınması ve standart enfeksiyon önlemlerine uyulması gerektiğini bir kez daha vurgulanması amaçlanmıştır.

\section{MATERYAL ve METOD}

Araştırma Kahramanmaraş Sütçü İmam Üniversitesi Sağlık Uygulama ve Araştırma Hastanesi’nde 2017-2018 yılları arasında çalışan 400 hastane personeline ait tarama kayıtlarının retrospektif olarak incelenerek yapılan kesitsel tipte tanımlayıcı bir çalışmadır. Tarama amacıyla alınan kan örneklerinde HBsAg ve Anti-HCV testleri laboratuarımızda kemilüminesans esasına dayanan "Enzyme-Linked Immunosorbent Assay" (ELISA) yöntemiyle çalışılmıştır. Bu çalışma için Sakarya Üniversitesi Tıp Fakültesi Etik Kurulundan 30.01.2019 tarihinde gerekli izin alınmıştır. Elde edilen veriler sayı ve yüzdelik hesaplama kullanılarak değerlendirilmiştir.

\section{BULGULAR}

Çalışmaya dahil edilen Kahramanmaraş Sütçü İmam Üniversitesi Sağlık Uygulama ve Araştırma Hastanesinde görevli 400 hastane personelinden 160 (\%40)'1 erkek 240 (\%60)'ı kadın olarak saptanmıştır. Personellerin 339'u (\%84.7) sağlık ekibi, 61’i (\%15.3) diğer çalışan grubundan oluşmaktadır. Sağlık ekibinin 263’ü (\%65.75) hemşire, 6’s1 (\%1.5) laborant, 35’i (\%8.75) sağlık teknisyeni, 2'si (\%0.5) hasta bakıc1, 14’ü (\%3.5) radyoloji teknisyeni, 5’i (\%1.25) eczac1, 2’si (\%0.5) diyetisyen, 4'ü (\%1) biyolog, 3’ü (\%0.75) psikolog ve 5'i (\%1.25) sağlık memurundan oluşmaktadır. Diğer çalışanlar ise 14'ü (\%3.5) bilgisayar işletmeni, 3’ü (\%0.75) şef, 3’ü (\%0.75) şoför, 11’i (\%2.75) teknisyen ve 30 ’u (\%7.5) memurdur. Sağlık çalışanının viral hepatitlere ait serolojik bulguları Tablo 1'de gösterilmiştir. 
Tablo 1. Sağlık çalışanlarının hepatit $B$ virüs ve hepatit $C$ virüs seroloji durumu

\begin{tabular}{|l|c|c|}
\hline Hepatit Serolojisi & Sayı & $\%$ \\
\hline Seronegatif & 389 & 97,25 \\
\hline HBsAg pozitifliği & 10 & 2,5 \\
\hline Anti-HCV pozitifliği & 1 & 0,25 \\
\hline Toplam & 400 & 100 \\
\hline
\end{tabular}

Hastane personelinin $10 \quad(\% 2,5)$ 'unda HBsAg, 1 $(\% 0,25)$ 'inde anti-HCV pozitif olarak bulunmuştur.

Sağlık çalışanlarının HBsAg ve Anti-HCV pozitifliği açısından meslek gruplarına göre dağılımı Tablo 2'de gösterilmiştir.

\begin{tabular}{|l|c|c|c|}
\hline \multicolumn{4}{|l|}{$\begin{array}{l}\text { Tablo 2. Sağlık çalışanlarının HBsAg ve Anti-HCV pozitifliği } \\
\text { açısından meslek gruplarına göre dağılımı }\end{array}$} \\
\hline $\begin{array}{l}\text { Meslek Gru- } \\
\text { pları }\end{array}$ & Toplam Sayı & $\begin{array}{c}\text { HBsAg Poziti- } \\
\text { fliği }\end{array}$ & $\begin{array}{c}\text { Anti-HCV } \\
\text { Pozitifliği }\end{array}$ \\
\hline Hemşire & $263(\% 65.75)$ & $5(\% 1.25)$ & - \\
\hline $\begin{array}{l}\text { Sağlık Tekn- } \\
\text { isyeni }\end{array}$ & $35(\% 8.75)$ & $2(\% 0.5)$ & - \\
\hline $\begin{array}{l}\text { Bilgisayar } \\
\text { I̧şletmeni }\end{array}$ & $14(\% 3.5)$ & $2(\% 0.5)$ & - \\
\hline $\begin{array}{l}\text { Radyoloji } \\
\text { Teknisyeni }\end{array}$ & $14(\% 3.5)$ & $1(\% 0.25)$ & - \\
\hline Laborant & $6(\% 1.5)$ & - & - \\
\hline Hasta Bakıcı & $2(\% 0.5)$ & - & - \\
\hline Şöför & $3(\% 0.75)$ & - & - \\
\hline Şef & $3(\% 0.75)$ & - & - \\
\hline Eczacı & $5(\% 1.25)$ & - & - \\
\hline Teknisyen & $11(\% 2.75)$ & - & - \\
\hline Memur & $30(\% 7.5)$ & - & - \\
\hline $\begin{array}{l}\text { Sağlık Me- } \\
\text { muru }\end{array}$ & $5(\% 1.25)$ & - & - \\
\hline Diyetisyen & $2(\% 0.5)$ & - & - \\
\hline Psikolog & $3(\% 0.75)$ & - & - \\
\hline Biyolog & $4(\% 1)$ & - & $-25)$ \\
\hline Toplam & $400(\% 100)$ & $10(\% 2.5)$ & - \\
\hline
\end{tabular}

\section{TARTIȘMA}

Sağlık personeli, kan ve kan ürünleri ile teması söz konusu olduğu için HCV, HBV bulaşması yönünden risk altında bulunmakla beraber kanında bu enfeksiyon etkenlerini ta-
Şıyan bir sağlık personelinin virüsü seronegatif hastalara bulaştırma ihtimali de söz konusudur. Bu bakımdan hastane personeline düzenli aralıklarla bu etkenler için serolojik tarama yapılmasının önemi büyüktür. Ülkemizde hepatit virüslerine maruziyette en önemli risk grubunu sağlık personeli oluşturmaktadır. Hepatitlerin sağlık çalışanlarına bulaşmasında kan ve kan ürünleri ile temasın yanı sıra hasta ile temas da önemlidir. Hekimler, hemşireler, laboratuar çalışanlarının yanı sıra örneklerin transportunu sağlayan personel ve temizlik personeli de risk grubunda bulunmaktadir. ${ }^{9}$

HBV ve HCV virüsü infekte materyallerle, tıbbi aletlerle, vücut salgılarıyla ve kan ürünleriyle hastadan hastaya, hastadan sağlık çalışanına ya da sağlık çalışanında hastaya bulaşabilir. ${ }^{10}$ Çalışmalar sağlık çalışanlarında HBV enfeksiyonu görülme sıklığının normal popülasyona göre 2-4 kat daha yüksek olduğunu göstermektedir. ${ }^{3}$ DSÖ verilerine göre tüm dünya genelinde her yıl meydana gelen 3 milyon perkütan yaralanma sonucunda, 70.000 HBV, $15.000 \mathrm{HCV}$ enfeksiyonu geliştiği bildirilmektedir. Ayrıca; hekimlerin her yılbaşına HBV enfeksiyonuna yakalanma riski \%0,61,4 olarak belirtilmiştir. Sağlık çalışanına bulaşın önlenmesi ancak ciddi güvenlik önlemlerinin alınması ile olur. Bununla birlikte HBV’ye karşı aşılanma da önerilmektedir. ${ }^{11} 1992$ yılında, Dünya Sağlık Örgütü (DSÖ) HBV enfeksiyonunu meslek hastalığı olarak kabul etmiş; 1996 yılında, T.C. Sağlık Bakanlığı sağlık çalışanlarının HBV yönünden taranıp uygun kişilerin aşılanmasını başlatmıştır. Aşılama programlarının yaygınlaşması, toplumsal bilincin ve farkındalığın artmasına rağmen, HBV enfeksiyonları halen önemini korumaktadır. ${ }^{6}$ Türkiye'de 1999-2009 yılları arasında yayınlanmış olan HBsAg prevalansı ile ilgili toplam 129 çalışmanın dâhil edildiği bir meta analizde, ülkemizde HBsAg prevalansı \%4.57 olarak hesaplanmıştır. ${ }^{12}$ Dünya Sağlık Örgütü (DSÖ) verilerine göre her yıl Avrupa'da 304 bin sağlık çalışanı HBV ile kontamine delici bir cisimle perkütan travmaya maruz kalmaktadır. ${ }^{13}$ Girişimsel işlemler sırasında sağlık personeline HBV bulaşma riski milyonda 2,4'tür. ${ }^{14}$ Amerika Birleşik Devletleri'nde 
kanla direkt teması olan medikal, dental ve laboratuar çal1şanlarında HBV prevalansı \%1-2 iken, kanla direkt teması olmayan sağllk personelinde prevalans $\% 0,3$ 'tür. Ülkemizde de sağlık personeli riskli grupta olup, bu oran \%2-14 olarak bildirilmektedir. ${ }^{15}$

Ülkemizde gerek sağlık çalışanlarında gerekse diğer gruplarda hepatit virüslerinin seroprevalansını araştırmak için çeşitli çalışmalar yapılmıştır. Hastane çalışanlarında HBV taşıyıcılı̆̆̆ının araştırıldığı değişik çalışmalarda, İnci ve ark. \%1, Kuru ve ark. \%3,6, Şencan ve ark. \%2, \%2,5, Baysal ve Kaya \%1,7, Ersöz ve ark. \% 2.0, Köse ve ark. \% 2.4 olarak bulmuşlardır., ${ }^{716-20}$ Çalışmamızda HBsAg seropozitifliği \% 2,5 olarak saptandi. HBsAg pozitifliği tespit edilen 10 personelimizin meslek gruplarına bakıldığında, 5’i hemşire, 2'si sağlık teknisyeni, 2'si bilgisayar işletmeni, 1'i radyoloji teknisyeni olduğu görüldü. Çalışmamızda HBsAg seropozitifliği ülkemizde yapılan diğer çalışmalarla benzerlik göstermektedir. Yurdumuzda HCV'nin prevalansı HBV'ye k1yasla daha düşük olmasına karşın sonuçları itibariyle hem normal popülasyon, hem de hastane personeli için önemlidir. ${ }^{21}$ Ülkemizde sağlık çalışanlarında HCV seroprevansının \%0,2-2,6 arasında olduğu bildirilmiş̧ir.22 İnci ve ark. $\% 0,34$,Baysal ve Kaya $\% 0,12$, Şencan ve ark. \%1.0, Öksüz ve ark. \%0,2, Aşkar \%0.15 olarak bulmuşlardır. ${ }^{717,18,23,24}$ Çalışmamizda $\% 0,25$ olarak saptanan anti-HCV seropozitiflik oranı yukarıdaki çalışmalarla benzerlik göstermektedir.

Sonuç olarak yüksek risk altında bulunan sağlık personellerini bu virüsler açısından taranması, HBV'ye karşı bağışık olmayanların aşılanması gerekmektedir. Ayrıca HBV ve HCV risklerinden dolayı sağlık çalışanlarına eğitimler verilerek bilinçlendirilmesi gerekliliğini ortaya koymuştur. 
Sakarya Tip Dergisi 2019;9(4):592-596

ARICAN ve Ark., Hepatit B Ve C Seroprevalansının Araştırılması

\section{Kaynaklar}

1. Akçam Z, Akçam M, Coşkun M, Sünbül M. Hastane personelinin viral hepatitler ve hepatit B aşısı ile ilgili bilgi düzeyinin değerlendirilmesi. Viral Hepatit Derg 2003;8:32-5.

2. Polat $M$, Öğüt S, Orhan H, Sucakl MB. Isparta ve Burdur'da çalş̧̧an hemșirelerin hepatit B virüs enfeksiyonu konusundaki bilgi, tutum ve davranışları. Viral Hepatit Derg 2006; 11:11;89-94.

3. Çetin M, Temiz M, Aslan A, Turhan E. Mustafa Kemal Üniversitesi Tip Fakültesi Hastanesi araștırma görevlilerinin hepatit B virusu infeksiyonuna ilişkin bilgi düzeylerinin değerlendirilmesi. Viral Hepatit Derg 2007;12:121-7.

4. Akca G. Diş Hekimliğinde Kan Yoluyla Bulaşan Viral İnfeksiyonlar ve Önemi. Hastane İnfeksiyonları Dergisi, 2008; 12:5-10.

5. Demir İ, Kaya S, Demirci M, Cicioğlu-Arıdoğan B. Isparta ili sağllk personelinde hepatit B virus seropozitiflĭginin araștrrılması. İnfeksiyon Derg, 2006; 20(3): 183-7.

6. Ergönül, Ö, Işık H, Baykan N, Erbay A, Dokuzoğuz B, Müftüoğlu O. Ankara Numune Eğitim ve Araştırma Hastanesỉnde sağlı çalışanlarında hepatit B enfeksiyonu. Viral Hepatit Derg 2001; 2: 3279 .

7. Inci M, Aksebzeci AT, Yağmur G, Kartal B, Emiroğlu M, Erdem Y. Hastane calı̧sanlarında HBV, HCV ve HIV seropozitifliğinin araștırılmast. Türk Hijyen ve Deneysel Biyoloji Dergisi 2009; 66(2): 59-66.

8. Tekay F. Hakkari ilinde HBV, HCV ve HIV seroprevalansi. Dicle Tip Derg, 2006; 33(3): 170-3.

9. Altun HU, Eraslan A, Özdemir G. İkinci Basamak Bir Hastanedeki Sağllk Çalışanlarının HBV, HCV VE HIV Seroprevalansları. Viral Hepatit Dergisi 2012;18(3):120-2.

10. Turunç T. Kan donörlerinde hepatit B ve hepatit C seroprevalansl. Viral Hepatit Derg 2003;8:171-3.

11. Phillips EK, Owusu-Ofori A, Jagger J. Blood borne pathogen exposure risk among surgeons in Sub-Saharan Africa. Infect Control Hosp Epidemiol 2007; 28: 1334-6.

12. Erişim tarihi: 17 Aralı 2011. Erişim adresi:http://www.vhsd.org/images/file_upload 9d3d5b7ffbcbe47674d1239b6cb02a9a58E21Q.pdf.
13. Puro V, De Carli G, Cicalini S, Soldani F, Balslev U, Begovac J et al. European recommendations for the management of healthcare workers occupationally exposed to hepatitis $B$ virus and hepatitis C virus. Euro Surveill, 2005; 10: 260-4.

14. Bonanni P, Pesavento, G, Boccalini S, Bechini A. Perspectives of public health: present and foreseen impact of vaccination on the epidemiology of hepatitis B. J Hepatol, 2003; 39: 224-9.

15. Mistık R, Balık I. Türkiye'de viral hepatitlerin epidemiyolojik analizi. In: Klliçturgay $K, B a$ dur S eds. Viral hepatit 2001. 1. Baskı. Ankara: Viral Hepatitle Savașım Derneği Yayını, 2001: 10-55.

16. Kuru U, Turan Ö, Kuru N, Sağlam Z, Ulucaklı Ö, Candan İ. Hastane çalışanlarında hepatitis B virusu infeksiyonu sıklı̆̆. Türkiye Kliniği Gastroenterohepatoloji Derg, 1994; 5:182-7.

17. Șencan, I., Șahin, İ., Kaya, D., Bahtiyar, Z.. Yeni kurulan bir tıp fakültesi hastanesi’nde sağlik çalışanlarının hepatit B ve hepatit C seroprevalansi. Viral Hepatit Derg. 2003; 8, 47-50.

18. Baysal B, Kaya Ș. Bir eğitim ve araștırma hastanesi personelinde HBV, HCV ve HIV seroprevalanst. Viral Hepatit Derg, 2012; 18(3): 94-7.

19. Ersöz G, Şahin E, Kandemir Ö ve ark. Mersin Üniversitesi Tip Fakültesi Hastanesi sağllk personelinde HAV, HBV, HCV seroprevalansı ve Hepatit B aşllaması, Viral Hepatit Derg 2006; 11(2):84-8.

20. Köse Ș, Sarıca A, Çevik FÇ, Cüce M. Yüksek risk grubunda olan sağllk çalışanlarında viral Hepatit A, B, C seroprevalansı, Viral Hepatit Derg 2003; 8(2):152-4.

21. Dilek İ, Demir C, Bay A, Akdeniz H, Öner A.F. Seropositivity rates of HBsAg, anti-HCV, anti-HIV and VDRL in blood donors in Eastern Turkey. Turk J. Hematol. 2007; 24, 4-7

22. Sünbül M. HCV enfeksiyonunun epidemiyolojisi ve korunma. Tabak F, Balık İ, Tekeli E, eds. Viral Hepatit 2007. 1. baskı. İstanbul: Viral Hepatitle Savaşım Derneği, 2007: 208-19.

23. Öksüz Ş, Yıldırım M, Özaydın Ç, Şahin İ, Arabacı H, Gemici G. Bir devlet hastanesi çalıșanlarında HBV ve HCV seroprevalansının araștırılması. ANKEM Derg, 2009; 23(1):30-3.

24. Așkar E. Sağllk çalışanlarında Hepatit B ve Hepatit C Seroprevalansı. Șişli Etfal Eğitim ve Araştırma Hastanesi Enfeksiyon Hastalkları ve Klinik Mikrobiyoloji Kliniği, uzmanlik tezi, Ístanbul: 2006. 